\title{
Responsive Leadership in Preventing Transmission of Covid-19 in the Indonesia-Malaysia Border Area
}

\author{
Oskar Hutagaluh \\ Institut Agama Islam Sultan Muhammad Syafiuddin Sambas, Indonesia \\ Andi Rustam \\ Universitas Muhammadiyah Makassar, Indonesia
}

Suwandi S. Sangadji

Universitas Nuku, Indonesia

Ilfan Baharuddin

Universitas Nuku, Indonesia

Ardhariksa Zukhruf Kurniullah

Universitas Mercu Buana, Indonesia

\begin{abstract}
The spread of the COVID-19 is increasingly globalized to have an impact not only on human health but also on all lines of life that requires rapid responses with anticipatory and preventive steps before its effects become worse. All countries feel the impact of outbreak, which moves so fast, including border communities. Today, COVID-19 travels through the human respiratory system to one another and from one area to another including Sambas area. The purpose of this study was to investigate the leadership responses and efforts to prevent the spread of this global disease on the Malaysia-Indonesia border area, precisely in the city of Sambas. We divided the findings into two. First, the spread of COVID-19 in Sambas was declared an extraordinary event category, because Sambas is located in the border area between Malaysia and Indonesia, where the community's largest livelihood is working in Malaysia. Second, when Sambas was declared an extraordinary category of the spread of that deadly virus, the local government responded to this incident by setting specific policies, including not carrying out religious or other rituals that invited crowds. On one hand. the Sambas community responded well to the policy. However, for certain reason the local Sambal are still carried out daily activities with the excuse for daily needs.
\end{abstract}

Keywords: Covid-19 Impacts, Responsive Leadership, Prevention, Sambas Border, Community responses

\section{Introduction}

The global prevention of Covid-19 is inseparable from the efforts of each country including the safeguarding of each border so that the spread is closely related to the responsiveness of the leaders of each country involving the latest set of rules and technology. History from time to time experienced by humans along with technological developments, it have made many people easy to travel and change people be global mobility higher. At the same time, it contributes to covid-19 is quickly transmitted all over the world. The fact that it has experienced a major wave of its originality in Wuhan, and spread to its neighbors and later eras to Europe and our country Indonesia. (Kong and Agarwal, P. P., 2020). The wave of spread passed by humans brings this virus to other humans with such a short time. (Zu, et al., 2020). They studied this Coronavirus 2019 outbreak in a perspective approach from China cases of deployment. Now known as the era of healing in the area of origin of this virus is contagious while other regions of the world are in the initial period of awakening with the seriousness of their respective governments so that the world seems shocked by the workings of fighting this Covid-19. (Crokidakis, 2020). This is proven in the data analysis and study modeling of the COVID-19 evaluation period in various parts of the world.

Seeing from the way it spreads, the disease attacks the respiratory system so that it experiences symptoms of fever, coughing and shortness of breath for 2-14 days. This virus first invaded China in December 31, 2019. This disease was initially considered to be mediocre, but several days to weeks this symptom continued so that thousands of Chinese people died. (Baldwin \& Tomiura, 2020; Page et al., 2020) This virus is increasingly spreading to other countries so that symptoms experienced by Chinese people are also experienced by other communities. Finally, patients who reach thousands of lives make hospitals, puskesmas unable to accommodate patients. (Hick and Biddinger, 2020). The medical team was also unable to find a vaccine to kill

DOI: $10.5373 / J A R D C S / V 12 I 2 / S 20201449$ 
this virus. (Ranney et al., 2020). The number of deaths is increasingly booming with thousands of lives so that each country anticipates that the country is safe from this virus.

The British Prime Minister, Boris Johnson held a press meeting on this issue with the medical team. The meeting warned the public that "more families will lose loved ones prematurely." If the community does not anticipate it first. (Hunter, 2020). Finally, almost 124 countries and regions are affected by the Covid pandemic, which results in death. (Emanuel et al., 2020). To prevent this from continuing, the government quarantined its people by imposing travel bans on China, the United States and other developing countries. However, deaths continue to increase. Quarantine is the separation of people from being exposed to infectious diseases, while isolation is people who are considered affected by this virus to be quarantined. (Parmet and Sinha, 2020). Each country carries out a policy of the impact of the Covid-19, for example the United States which issued a policy on immigration by restricting entry into America. (Page et al., 2020). Indonesia also provides a policy so that this deadly virus does not occur in Indonesia. However, with the development of sophisticated technology, Indonesian people who visited foreign countries using airplanes and returning from abroad brought this deadly virus. Finally, gradually some Indonesian people were tested positive for Corona virus.

Indonesian people affected by the Covid-19 have reached thousands of people, dated March 1, 2020 has reached 1,414 people(World Health Organization, 2020). Covid virus is most easily affected by people who are elderly, sick and lacking immunity (Rose, 2020). On March 11, 2020, the world health organization established (Covid-19) as a global pandemic (Ranney et al., 2020), which until now Covid-19 had not yet found a vaccine and no therapy was used to treat it. this disease(Cao et al., 2020). To avoid it using a mask, washing hands, when coughing cover with hands, staying at home and a healthy lifestyle (Hick and Biddinger, 2020). This deadly virus quickly moves to one country to another country, to one region to another so that it also seeps in the Border areas of Indonesia and Malaysia in the Sambas region.

Sambas with an area of 639,570 ha, has various ethnic types. Sambas has 19 sub-districts and 183 villages (Aslan, 2019); (Aslan et al., 2019); (Aslan and Hifza, 2020). Sambas is part of the West Kalimantan region with 4504 people monitored on April 1. Sambas numbered 499 people and has been completed in monitoring 499 people. A number of people were monitored and tested positive for Covid's death. Sambas, which is located in the border area of Malaysia and as a place for entry and exit for Indonesians and Malaysians, both to go to visit and to go to work. Moreover, the roads in Temajuk which are not so tight make Indonesians or Malaysians easily go to Indonesia. So that the Covid-19 is not more contagious in Sambas, the local government makes a policy for the community to work together to break the chain of the covid virus. The researcher felt interested to study further about the efforts of the majority of the Malaysia-Indonesia border in Sambas in response, efforts to tackle the spread of Covid-19 by collaborating with various parties and the Sambas community in general.

\section{Research Methods}

This research is a qualitative study. Data collection was carried out using observation, documentation and semi-structured interview techniques (Berg, 2001; Creswell, 2009). Observation was carried out by monitoring the Sambas area which is high in the case of the spread of COVID-19. While the interview session is done through online interaction. The reason is because in April 2020, the Sambas community is still in the period of stay home and social distancing or for the prohibition of crowds, so that the congregational prayer was held at home. Interviews were conducted with a number of villages in Sambas District. Meanwhile, documentation is a document issued by the region regarding the handling of COVID-19 cases in Sambas.

In this accordance with Hancock et al., (2009)said that interview techniques can also be carried out online, in contrast to observations that require arriving at the object of study. This is in accordance with the emergency conditions of Covid-19, the exceptional case area in Sambas. Meanwhile, the data analysis method uses the theory of Matthew B. Miles A Michael Huberman, (1994)

namely data presentation, data reduction and data verification. Appropriate data will be taken in accordance with this study. Researchers also use the study of literary theory as stated (Zed, 2008)that the study of literature is not merely collecting literature, but looking for gaps in the problem and making new literature.

\section{Results and Discussion}

The COVID-19 cases reported in Wuhan, China have affected 57 countries and caused 2942 deaths in 9 countries(Lai et al., 2020). COVID-19 originates from Wuhan city, Hubei Province of China and spreads in various countries of the world ( $\mathrm{Li}$ et al., 2020). COVID-19 is a new disease caused by infection with "Severe Acute Respiratory Syndrome Coronavirus 2 (SARS-CoV-2)". Symptoms experienced by COVID-19, such as "common cold (fever, cough, runny nose, sore throat, muscle aches, headache) to severe complications (pneumonia or sepsis)". This method of transmission of COVID-19 is through splashing when coughing, sneezing or talking, physical contact such as shaking hands, touching the mouth, nose and eyes with the affected hands. (Razi et al., 2020). The COVID-19 with transmission is so easy that every day the death toll increases. 
The virus not only claimed so many victims but spread throughout the world, including in Indonesia in general and the Sambas region in particular.

Sambas is one part of the West Kalimantan region and the impact of the covid-19, finally Sambas was designated as a category of serious effected area. This determination is inseparable from the Indonesian Workers who work in Malaysia. The virus spread to Sambas through migrant workers who returned to work in Malaysia and some were sent home. Moreover, Sambas is a border area between two countries, Indonesia and Malaysia, making it more vulnerable to the entry of the Covid -19 in Sambas. In addition, the biggest livelihood of the Sambas people is Malaysia. secondly the influence of Sambas as a border road between Malaysia and Indonesia and as the livelihood of the Sambas people so that the establishment of Sambas as a category of seriously effected.

Based on information updates dated March 27, 2020, a number of 1971, people who were included in the list of people under monitoring. Meanwhile, in the supervision of 582 people (Nasaruddin, 2020). So Individuals who fall into the category of surveillance patients (PDP), one of whom has died at the Manggis Sambas hospital on March 28, 2020 (Bob, 2020). The covid-19 virus incident was finally gradually realized by the Regional Government and the Sambas community. Regional head by giving an appeal to the people of Sambas to always be vigilant against the covid virus 19. The regional head is as a leader for the Sambas community, because the covid-19 if not anticipated early by the region, will have a big impact like other countries that consider the covid virus 19 is an ordinary virus.

Leadership is something very important that the success of an organization or a company is inseparable from the leadership role (Zhang, 2020). Elements of leadership include motivation, shared values, social cohesion and institutional renewal (Gardner and Gardner, 1993). From these elements the birth of leadership style that is almost possessed by every leader (Sadler, 2003). The COVID-19 events that plague all over the world, including in Indonesia, require innovation in leadership.

Leadership innovation is a leader who takes policies for the benefit of together (Curry-Stevens, 2018). The benefit is a policy that has a great impact on society, so that the innovation of its leadership gives birth to a leadership style that recognizes the situations and conditions experienced by the community. In terms of leadership, such leaders are known as responsive leadership.

Responsive leadership is a leader who sees a problem or obstacle involving many parties or the community(Tjahjono, 2011); (Arief, 2018). Covid-19 that has spread in Sambas, finally as the head of the region took steps to issue a policy for the people of Sambas. On March 26, 2020, the Regent of Sambas appealed to the Sambas community about delaying the crowd, and conducting religious worship after the establishment of the Covid-19 a most effected areas status in Sambas Regency" (Suhaili, 2020). The stipulation document contains about; First, delaying the implementation of activities involving the public at large by referring to the "Indonesian National Police Chief Regulation dated March 19, 2020". Second, the implementation of worship for Muslims in Sambas District with reference to the "Fatwa of the Indonesian Ulema Council document: 14 of 2020 concerning the organization of Worship in the event of the Covid-19 outbreak, Tausyiah of the Indonesian Ulema Council (MUI) of West Kalimantan Province Number: 24 / MUIKB / III / 2020, appeal from Head of Sambas Regency Religion Ministry Office Number: P-320 / Kk. 14.05.6 / BA.00 / 03/2020 dated March 23, 2020 and Tausyaih of the Indonesian Ulema Council (MUI) of Sambas Regency Number: 15 / MUI-SBS / B / III / 2020 concerning worship carrying out mosque worship.

The regulation as follows: to the caretakers of the mosque, the mosque and all Muslims not to perform Friday prayers and to perform the midday prayers in their homes; b). The mosque / public pray management should not hold the obligatory prayer in congregation, but the prayer prayer is always echoed as evidence of the entry of prayer times; c). Do not hold religious activities that involve many people, whether carried out in the mosque or elsewhere. Third, for religions other than Islam, heed the direction of their respective religious assemblies and heed the appeal of the Head of the Sambas Religion Ministry Office. Fourth, during the worship at their respective homes, the mosque / surau, mushalla and other religious management should maintain the cleanliness of their respective traditional houses of worship and worship. Fifth, for the whole Sambas community to reduce activities outside the home, stay in the house a lot, maintain physical distance, cosupervise the spread and transmission and report to the Head of the Sambas District Health Office. Sixth, this appeal will be changed according to the current time and conditions.

Sambas regional government regulations, regarding COVID 19 emergency areas in Sambas, also follow the policies of the Indonesian National Police (Azis, 2020). The essence of the Police document is so that it does not make the crowd as long as the COVID-19 virus has not been lost so it does not affect the other Sambas people. Then, it is forbidden to hold social, cultural, religious gatherings, streams of belief in the form of seminars, workshops, gatherings and other activities that are considered similar. Furthermore, it is forbidden to hold music concerts, fairs, festivals, bazaars, night markets, exhibitions, and family receptions, sports activities, arts and entertainment services, rallies, marches and carnivals as well as other activities where mass gatherings occur. Prohibition of activities to hold a party and involve many people and also prohibited from

DOI: $10.5373 / J A R D C S / V 12 I 2 / S 20201449$

*Corresponding Author: Oskar Hutagaluh, E-mail: oskarhutagaluh@iaisambas.ac.id

Article History: Received: Jan 12, 2020, Accepted: Mar 15, 2020 
holding prayers in congregation at the mosque during the covid-19 period approved by the Indonesian Ulema Council of West Kalimantan Province,(H. M. Basri HAR and Abdillah, 2020), Ministry of Religion Sambas (2020) and the Sambas Regency Indonesian Ulema Council (Syafiuddin and Asmawi, 2020).

The policy set by the local government to the people of Sambas is a symbol to be followed and implemented. Herbert, (1969), Blumer, (1986), Cassirer, (1994)as adherents of symbols, that humans in their lives are inseparable from culture bound by symbols and have meaning that needs to be interpreted by society(Geertz, 1973). Symbols are only interpreted by the public as the makers of these symbols in the form of language and are carried out interactively, print media, electronic media, online media and other media. Meanwhile, the symbol of COVID-19 handling in Sambas, through print and online media, which is distributed in Sambas areas through pamphlets, brochures, banners and others to be obeyed by the community and carried out by the Sambas community as a whole.

According to the results of several interviews of some Sambas people from several districts over the establishment of Sambas as an extraordinary category about the covid-19, the Sambas people have started to panic and have an impact on the economic system under the Sambas community, for example the Sambas people have started losing their jobs, because the community is not allowed to move or get out of the house, except about important business matters. The price of staples rises, for example sugar, while community staple jobs such as sap jumps to three thousand rupiah per kilo. The price of the gum with the base price is very different. Between income income is out of balance with cost of goods.

Events that invite crowds such as recitals, weddings, meetings, associations, etc. have started to not be carried out by the Sambas community, for example, the shamanic event which is usually done every year before fasting is also abolished (Julianti, 2020); (Listari, 2020); (Mirawati, 2020). The local government also determined not to pray in congregation at the mosque and at home, including no more Friday prayers during the Covid-19 and replaced with the midday prayer which was imposed on March 27, 2020. Call for prayer is still performed as symbol of the sign entered prayer time (Safitri, 2020); (Marianti, 2020). Meanwhile, for civil servants whose professions as teachers dismiss their respective schools but the teacher still runs administration in the school, so there is no new economic impact on teachers and other civil servants.

The Sambas community has also begun to fear and to cure the fear, the community spraying every house, mosque, school, and keeping the carpet and prayer rug clean, urging the worshipers to bring prayer rugs from their homes, giving direction to the population to prevent Covid-19 by washing hand with soap and running water and provide a sink as a place to wash hands (Eriyani, 2020); (Yanti, 2020); (Natalia, 2020). In the village of Makrampai Sambas, spraying was carried out by mosque youth and the community(Marianti, 2020). Village leaders like Sebangun village held a meeting between the village head and the RT head to discuss how the virus would not spread in their respective areas (Eriyani, 2020). The Sambas community compactly works together to maintain cleanliness (Marianti, 2020). However, not all Sambas people consisting of several parts of the village carried out orders from the regional head, the Indonesian Ulema Council, and the village head about the covid virus 19 from establishing Sambas as an extraordinary region.

The results of interviews conducted with Lisma, (2020)as one of the Mekar Sekuntum and Asmin, (2020)villages as the Tri Kembang village community responded to the local government policy for the impact of the Mekar Sekuntum community over the establishment of Sambas as an extraordinary event Covid-19. Communities that have not aware of the deadly covid-19 virus outbreak still carrying out its daily activities (Mirawati, 2020)for example experienced by the Sepudak community, where many young people still leave the house and gather in groups. Even in religious matters, such as studying the Koran after sunset is still being carried out (Lisa, 2020). Some of the Sambas people about Lock down in Sambas were not taken seriously.

According to Yusmayanti, (2020)as a Lorong Sambas village community, giving an opinion related to lock down, which for the lock down in Sambas is not necessary, because the covid-19 virus, is still not widespread in Sambas. The Sambas community still conducts daily activities, such as selling and opening places of worship, but does not carry out events that invite the public at large. This incident was also carried out in the village of Setalik, some people still carry out their daily activities on the grounds that if they do not go to work, then they cannot fulfill their daily needs. The government should provide basic necessities at home, so that people adhere to government regulations (Nurelisa, 2020). The lower economic community, who daily open a coffee shop every day, who usually invites many people, but the impact of the covid symptoms of a coffee shop is still open but for those who drink coffee no longer in the shop just wrapped in plastic (Fazira, 2020). For the people of Sambas who do not heed the Regent's decree, the Police will raid these places and disperse those who are still doing the crowd in Sambas (Safitri, 2020).

Thus, from the results of interviews, observations and documentation conducted on the Sambas community from several villages that are part of the Sambas Regency about responding to the Covid 19 virus problem, as determined by local government policy, on one hand it follows the policy and on the other hand it does not follow for economic reasons. 


\section{Conclusion}

The COVID-19 which initially occurred in Wuhan, China by attacking human breathing and other symptoms resulting in many deaths, eventually spread also in countries around the world that are no exception also in Indonesia in general and Sambas in particular. The results of research conducted in Sambas Regency and several village areas which are still under the Sambas area administration, then there are findings in the study; First, the Covid-19 in Sambas is declared a category of extraordinary events, a serious effected area, because Sambas is in the border area between two countries Malaysia and Indonesia and the biggest livelihood of the Sambas people is to Malaysia. Second, when Sambas is declared as a serious effected area category, the local government is very responsive to the incident so that it sets policies to be followed by the Sambas community, including not carrying out religious or other rituals that invite many people. On one side the Sambas community carries out the policy, but on the other hand it still carries out daily activities with the excuse for daily needs.

\section{References}

[1] Arief, A.B., 2018. The Good, Bad and Bandit Leadership. Gramedia Pustaka Utama, Jakarta.

[2] Aslan, 2019. Pergeseran Nilai Di Masyarakat Perbatasan (Studi tentang Pendidikan dan Perubahan Sosial di Desa Temajuk Kalimantan Barat) (Disertasi). UIN Antasari Banjarmasin, Banjarmasin.

[3] Aslan, Hifza, 2020. The Community Of Temajuk Border Education Values Paradigm On The School. International Journal of Humanities, Religion and Social Science 4, 13-20.

[4] Aslan, Setiawan, A., Hifza, 2019. Peran Pendidikan dalam Merubah Karakter Masyarakat Dampak Akulturasi Budaya di Temajuk. FENOMENA 11, 11-30.

[5] Azis, I., 2020. Maklumat Kepala Kepolisian Negara Republik Indonesia tentang Kepatuhan Terhadap Kebijakan Pemerintah Dalam Penanganan Penyebaran Virus Corona (COVID-19).

[6] Blumer, H., 1986. Symbolic Interactionism Perspective and Method, 1st ed. University of California Press Berkeley and Los Angeles, California.

[7] Bob, 2020. Satu PDP di Sambas Meninggal Dunia [WWW Document]. Suarapemredkalbar.com. URL https://www.suarapemredkalbar.com/read/sambas/28032020/satu-pdp-di-sambas-meninggal-dunia (accessed 4.1.20).

[8] Cao, B., Wang, Y., Wen, D., Liu, W., Wang, Jingli, Fan, G., Ruan, L., Song, B., Cai, Y., Wei, M., Li, X., Xia, J., Chen, N., Xiang, J., Yu, T., Bai, T., Xie, X., Zhang, L., Li, C., Yuan, Y., Chen, H., Li, Huadong, Huang, H., Tu, S., Gong, F., Liu, Y., Wei, Y., Dong, C., Zhou, F., Gu, X., Xu, J., Liu, Z., Zhang, Y., Li, Hui, Shang, L., Wang, K., Li, K., Zhou, X., Dong, X., Qu, Z., Lu, S., Hu, X., Ruan, S., Luo, S., Wu, J., Peng, L., Cheng, F., Pan, L., Zou, J., Jia, C., Wang, Juan, Liu, X., Wang, S., Wu, X., Ge, Q., He, J., Zhan, H., Qiu, F., Guo, L., Huang, C., Jaki, T., Hayden, F.G., Horby, P.W., Zhang, D., Wang, C., 2020. A Trial of Lopinavir-Ritonavir in Adults Hospitalized with Severe Covid-19. New England Journal of Medicine 0, 1-13. https://doi.org/10.1056/NEJMoa2001282

[9] Cassirer, E., 1994. An Essay on Man, An Introduction to Philosophy of Human Culture. University Press, New York.

[10] Curry-Stevens, A., 2018. Innovations in Leadership Development: Centering Communities of Color. Open Journal of Leadership 7, 265-284. https://doi.org/10.4236/oj1.2018.74016

[11]Emanuel, E.J., Persad, G., Upshur, R., Thome, B., Parker, M., Glickman, A., Zhang, C., Boyle, C., Smith, M., Phillips, J.P., 2020. Fair Allocation of Scarce Medical Resources in the Time of Covid-19. New England Journal of Medicine 0, 1-7. https://doi.org/10.1056/NEJMsb2005114

[12] Eriyani, 2020. Kebijakan Pemerintah Daearah Tentang Covid-19 di Sambas.

[13] Fazira, 2020. Kebijakan Pemerintah Daearah Tentang Covid-19 di Sambas.

[14] Gardner, J., Gardner, J.W., 1993. On Leadership. Simon and Schuster, New York.

[15] Geertz, C., 1973. The Interpretation Of Cultures. Basic Books, Inc., Publisher, New York.

[16] H. M. Basri HAR, Abdillah, Z., 2020. Majelis Ulama Indonesia Provinsi Kalimantan Barat tentang Tausiyah Majelis Ulama Indonesia Provinsi Kalimantan Barat Tentang Penyelenggaraan Ibadah di Masjid Dalam Situasi Darurat Covid-19.

[17] Hancock, B., Ockleford, E., Windridge, K., 2009. An Introduction to Qualitative Research. University of Sheffield regent Court, Yorkshire \& The Humber.

[18] Herbert, B., 1969. Symbolic Interactionism: Perspective and Method. Cliiff NJ, Englewood.

[19] Hick, J.L., Biddinger, P.D., 2020. Novel Coronavirus and Old Lessons - Preparing the Health System for the Pandemic. New England Journal of Medicine 0, 1-3. https://doi.org/10.1056/NEJMp2005118

[20]Hunter, D.J., 2020. Covid-19 and the Stiff Upper Lip - The Pandemic Response in the United Kingdom. New England Journal of Medicine 0, 1-3. https://doi.org/10.1056/NEJMp2005755

[21] Julianti, L., 2020. Kebijakan Pemerintah Daearah Tentang Covid-19 di Sambas.

DOI: $10.5373 / J A R D C S / V 12 I 2 / S 20201449$

*Corresponding Author: Oskar Hutagaluh, E-mail: oskarhutagaluh@iaisambas.ac.id

Article History: Received: Jan 12, 2020, Accepted: Mar 15, 2020 
[22] Kong, W., Agarwal, P. P., 2020. Chest imaging appearance of COVID-19 infection. Radiology: Cardiothoracic Imaging 2, 20-28.

[23] Lai, C.-C., Wang, C.-Y., Wang, Y.-H., Hsueh, S.-C., Ko, W.-C., Hsueh, P.-R., 2020. Global epidemiology of coronavirus disease 2019 (COVID-19): disease incidence, daily cumulative index, mortality, and their association with country healthcare resources and economic status. International Journal of Antimicrobial Agents 16, 1-8. https://doi.org/10.1016/j.ijantimicag.2020.105946

[24] Li, H., Liu, S.-M., Yu, X.-H., Tang, S.-L., Tang, C.-K., 2020. Coronavirus disease 2019 (COVID-19): current status and future perspective. International Journal of Antimicrobial Agents 1-37. https://doi.org/10.1016/j.ijantimicag.2020.105951

[25] Matthew B. Miles A Michael Huberman, 1994. Qualitative Data Analysis: an expanded sourcebook. SAGE Publication, London.

[26] Nasaruddin, 2020. Update Data PDP, ODP dan Positif Virus Corona di Kalbar, Sabtu 28 Maret 2020 [WWW Document]. Tribun Pontianak. URL https://pontianak.tribunnews.com/2020/03/28/updatedata-pdp-odp-dan-positiv-virus-corona-di-kalbar-sabtu-28-maret-2020 (accessed 4.1.20).

[27] Page, K.R., Venkataramani, M., Beyrer, C., Polk, S., 2020. Undocumented U.S. Immigrants and Covid-19. New England Journal of Medicine 0, 1-3. https://doi.org/10.1056/NEJMp2005953

[28] Parmet, W.E., Sinha, M.S., 2020. Covid-19 - The Law and Limits of Quarantine. New England Journal of Medicine 0, 1-3. https://doi.org/10.1056/NEJMp2004211

[29] Ranney, M.L., Griffeth, V., Jha, A.K., 2020. Critical Supply Shortages - The Need for Ventilators and Personal Protective Equipment during the Covid-19 Pandemic. New England Journal of Medicine 0, null. https://doi.org/10.1056/NEJMp2006141

[30] Razi, F., Yulianty, V., Amani, S.A., Jimny Hilda Fauzia, 2020. Bunga Rampai Covid-19: Buku Kesehatan Mandiri Untuk Sahabat \#dirumahaja., Ed., Dumilah Ayuningtyas. PD Prokami Kota Depok, Depok.

[31] Rose, C., 2020. Am I Part of the Cure or Am I Part of the Disease? Keeping Coronavirus Out When a Doctor Comes Home. New England Journal of Medicine 0, 1-3. https://doi.org/10.1056/NEJMp2004768

[32] Sadler, P., 2003. Leadership. Kogan Page Publishers, USA.

[33] Safitri, E., 2020. Kebijakan Pemerintah Daearah Tentang Covid-19 di Sambas.

[34] Suhaili, H.A.R., 2020. Penundaan keramaian, dan pelaksanaan ibadat umat beragama pasca penetapan status KLB Covid-19 di Kabupaten Sambas.

[35] Syafiuddin, H.S., Asmawi, H.S., 2020. Majelis Ulama Indonesia Kabupaten Sambas.

[36] Tjahjono, H., 2011. Culture Based Leadership. PT Gramedia Pustaka Utama, Jakarta.

[37] World Health Organization, 2020. Coronavirus disease 2019 (COVID-19).

[38]Zed, M., 2008. Metode Penelitian Kepustakaan. Yayasan Obor Indonesia, Jakarta.

[39] Zhang, X., 2020. The Relationship of Coaching Leadership and Innovation Behavior: Dual Mediation Model for Individuals and Teams across Levels. Open Journal of Leadership 9, $70-83$. https://doi.org/10.4236/oj1.2020.91005

\section{List of Interviewees:}

Asmin, 2020. Kebijakan Pemerintah Daearah Tentang Covid-19 di Sambas. Lisa, 2020. Kebijakan Pemerintah Daearah Tentang Covid-19 di Sambas. Lisma, 2020. Kebijakan Pemerintah Daearah Tentang Covid-19 di Sambas. Listari, 2020. Kebijakan Pemerintah Daearah Tentang Covid-19 di Sambas. Marianti, 2020. Kebijakan Pemerintah Daearah Tentang Covid-19 di Sambas. Mirawati, 2020. Kebijakan Pemerintah Daearah Tentang Covid-19 di Sambas. Natalia, D., 2020. Kebijakan Pemerintah Daearah Tentang Covid-19 di Sambas. Nurelisa, 2020. Kebijakan Pemerintah Daearah Tentang Covid-19 di Sambas. Yanti, R.E., 2020. Kebijakan Pemerintah Daearah Tentang Covid-19 di Sambas. Yusmayanti, L., 2020. Kebijakan Pemerintah Daearah Tentang Covid-19 di Sambas. 